\title{
PERENCANAAN STRATEGIK USAHA KECIL MENENGAH JENIS USAHA KUE DAN ROTI
}

\author{
Dianka Wahyuningtias \\ Jurusan Hotel Manajemen, Fakultas Ekonomi dan Bisnis, Bina Nusantara University \\ Jln. K.H. Syahdan No. 9, Kemanggisan, Palmerah, Jakarta Barat 11480
}

\begin{abstract}
Strategy is needed to sustainable business the year to come. This study is a descriptive case study using primary and secondary data which was collected from interviews, observations and literatures. Through a development strategy will be found various strategy which could be applicable by a company. The purpose of this research is to identify and evaluate the internal and external strategically factors of the company in UKM and to formulate several strategy alternatives applicable in developing UKM business develop program. Based on the TOWS matrix analysis, six alternatives strategies were produced, which includes having the own bakery shop, expanding partnership with bakeries in the jabodetabek area, implementing a differentiation products, increasing marketing activities, purposing bank loan, and investing on right equipment. After defining the conclusion, it is expected that UKM business, especially food industry, could use them to develop their business.
\end{abstract}

Keywords: food industry, UKM business, strategic planning

\begin{abstract}
ABSTRAK
Strategi dibutuhkan untuk melestarikan bisnis di masa mendatang. Penelitian ini merupakan sebuah studi kasus deskriptif menggunakan data primer dan sekunder yang dikumpulkan dari wawancara, observasi, dan literatur. Melalui strategi pengembangan akan ditemukan beberapa macam strategi yang bisa diterapkan oleh perusahaan. Tujuan penelitian ini yaitu untuk mengidentifikasi dan evaluasi faktor strategi internal dan eksternal perusahaan dan untuk memformulasikan alternatif strategi yang bisa diaplikasikan dalam program pengembangan bisnis usaha kecil menengah. Berdasarkan analisis matriks TOWS, enam strategi alternatif diterapkan, yaitu memiliki toko roti, melebarkan hubungan partnership dengan toko-toko roti di area Jabodetabek, mengimplementasikan produk diferesiasi, meningkatkan aktivitas marketing, meminjam pada bank, dan berinvestasi yang benar. Melihat simpulan yang ada maka dapat diharapkan industri UKM, terutama industri pangan, dapat mempergunakannya untuk pengembangan usahanya.
\end{abstract}

Kata kunci: industri pangan, bisnis UKM, perencanaan strategik 


\section{PENDAHULUAN}

\section{Latar Belakang Masalah}

Perencanaan strategik mutlak diperlukan oleh organisasi untuk menentukan strategi-strategi yang tepat dalam mecapai tujuan perusahaan. Penyusunan perencanaan strategik tidaklah mudah, perencanaan strategik bukanlah hanya pada hasil perencanaan strategik, melainkan bagaimana proses membentuk perencanaan strategik, sehingga perencanaan strategik tersebut tepat digunakan atau diterapkan dalam merealisasikan tujuan perusahaan. Perencanaan strategik harus bersifat objektif, realistis dan fleksibel (mudah diterapkan), mampu membimbing organisasi untuk merealisasikan program masa depan perusahaan, mengevaluasi bagaimana program ini dilakukan serta membuat penilaian-penilaian ketika diperlukan.

Untuk membahas suatu perencanaan strategis hendaknya kita mengacu pada model perencanaan strategis agar pembahasannya terfokus. Ibaratnya, kita akan mendiskusikan pesawat terbang, paling tidak kita sudah tahu gambaran tentang pesawat terbang yang umum, bahwa pesawat terbang berfungsi sebagai alat pengangkut lewat udara yang bagian-bagiannya antara lain sayap, tempat duduk, dan kokpit. Perencanaan strategik harus mampu merefleksikan pikiran, perasaan, ideide perusahaan. Setiap unit yang terlibat dalam organisasi harus menerima, menyetujui dan megimplementasikan hasil perencanaan strategik. Selain implementasi perencanaan harus efektif dan efisien, semua individu dalam perusahaan harus terlibat di dalamnya. Berdasarkan, kompleksnya proses perencanaan strategik, maka makalah ini disusun.

\section{Tujuan}

Makalah ini bertujuan untuk menggambarkan perencanaan strategik yang dapat digunakan perusahaan kecil menengah (UKM) untuk jenis usaha produksi pangan (kue, roti, dan makanan).

\section{Telaah Pustaka}

\section{Pengertian Strategi}

Perencanaan merupakan proses membentuk sasaran perusahaan dan memilih cara yang sesuai untuk mengambil tindakan tertentu dalam mencapai sasaran utama perusahaan. Ackoff (1978), mendefinisikan perencanaan sebagai proses pengambilan keputusan sebelum tindakan dilaksanakan. Perencanaan sebagai suatu proses yang membimbing para anggota organisasi dalam mencapai sasaran masa depan organisasi dan membentuk prosedur penting serta operasi kerja untuk mencapai masa depan organisasi.

Setiap perusahaan baik besar maupun kecil membutuhkan strategi dalam setiap kegiatan yang dilakukannya. Hal ini bertujuan agar setiap kegiatan yang terjadi menjadi semakin efektif dan efisien. Strategi dapat dipandang sebagai suatu cara organisasi untuk mencapai tujuan jangka panjangnya (Hussey, 1999). Penjelasan lebih terperinci mengenai tujuan jangka panjang suatu perusahaan dan bagaimana cara perusahaan mencapainya terdapat di dalam perencanaan strategis. Menurut Hussey (1999) proses pengaturan tujuan jangka panjang, strategi dan pelaksanaannya disebut sebagai manajemen strategik. 


\section{METODOLOGI PENELITIAN}

\section{Metode Penelitian}

Dalam penelitian, metode yang digunakan adalah metode dskriptif. Dengan metode ini dapat ditentukan faktor-faktor eksternal dan internal strategic. Metode penelitian yang digunakan adalah studi kasus dalam bentuk deskriptif dengan mempelajari masalah yang terjadi di UKM jenis usaha makanan. Penggunaan metode Deskriptif ditujukan untuk memperoleh gambaran, informasi, penjelasan, dan kondisi yang berkaitan dengan obyek penelitian pada saat sekarang. Dengan metode ini diharapkan memperoleh gambaran mengenai sifat suatu keadaan yang tengah berlangsung pada saat penelitian dilaksanakan, dan memeriksa sebab-sebab dari suatu gejala tertentu.

\section{Jenis dan Sumber Data}

Data yang diperlukan terdiri dari data primer. Data primer adalah data yang diperoleh melalui hasil wawancara, diskusi kepada responden tertentu. Data sekunder merupakan data yang diperoleh dari sumber internal perusahaan, studi pustaka, media cetak dan elektronik, serta informasi lain yang berkaitan dengan topik penelitian.

\section{Teknik Pengumpulan Data dan Informasi}

Pengumpulan data pada penelitian ini dilaksanakan dengan menggunakan beberapa teknik. Data Primer diperoleh dari hasil pengamatan dan kegiatan ini dilakukan dengan wawancara oleh responden internal perusahaan dan responden eksternal perusahaan (pakar di bidang makanan seperti, perhimpunan bakery, pengajar di bidang makanan, anggota asosiasi chef Indonesia). Sedangkan data sekunder diperoleh dari berbagai sumber yang mendukung studi ini antara lain dalam perusahaan, instansi terkait, internet, dan studi pustaka lainnya yang berkaitan dengan studi ini.

\section{Teknik Pengambilan Contoh}

Teknik pengumpulan data primer untuk menyusun sebuah strategi menggunakan teknik purposive sampling yaitu pengambilan sampel secara sengaja terhadap beberapa responden yang telah ditetapkan berdasarkan jabatan, posisi, pengetahuan, dan faktor lain yang menunjukkan kompetensi responden terhadap topik penelitian (Cooper \& Schindler, 2006).

\section{HASIL DAN PEMBAHASAN}

Analisis lingkungan eksternal dan internal pada penelitian ini dilaksanakan untuk mengkaji berbagai faktor eksternal internal yang berpengaruh terhadap strategi pengembangan UKM. Faktorfaktor strategis lingkungan eksternal internal terdiri dari faktor-faktor peluang dan ancaman, kekuatan dan kelemahan bagi pengembangan UKM. Peluang merupakan faktor strategis eksternal yang harus dimanfaatkan dengan sebaik-baiknya untuk mencapai tujuan dalam rangka pengembangan UKM.

Faktor eksternal yang termasuk dalam kategori peluang adalah: (1) peningkatan konsumsi masyarakat terhadap produk berbasis terigu. Menurut data wheat seminar equipment and ingredients for bakery sector di Vietnam pada November 2009, dikatakan bahwa pertumbuhan konsumsi terigu di Indonesia pada periode 1998-2009 mencapai 7\%, sedangkan pertumbuhan konsumsi beras hanya 1\%. (2) Pertumbuhan usaha kue yang meningkat. Pada data Euro monitor internasional yang dirilis November 2008, jumlah kue yang diproduksi oleh industri kue di Indonesia pada tahun 2008 mencapai 6,4 juta ton. Nilai dari penjualan kue di kelas industry mencapai Rp.2,9 milyar. 
Pertumbuhan usaha kue pada tahun 2003-2008 mencapai 9,7 berdasarkan volume tonase. Sedangkan berdasarkan nilai rupiah mencapai $66 \%$.

(3) Perkembangan inovasi kue yang sangat pesat. Pada seminar yang diadakan majalah bakey dengan tema "Reformulating Business By innovation menyebutkan Inovasi kue bagi pengusaha kue Indonesia dapat dimulai dari penguasaan secara mendalam fungsi dan aplikasi bahan baku utama (selain tepung terigu) seperti tepung beras, tepung beras ketan, tepung ubi jalar, tepung singkong, sagu, dan tepung lainnya yang dapat diproduksi di Indonesia. Semua tepung-tepungan non terigu dapat dicampur dengan tepung terigu dan diaplikasikan dalam semua produk bakery (bread, cake dan pastry) seperti yang sudah dilakukan oleh baker jepang dan Taiwan. Pengusaha bakery Taiwan sudah mencampurkan tepung beras 30\% dengan tepung terigu untuk berbagai inovasi produk bakery nya yang baru dan dimulai sejak 5 tahun lalu.

(4) Perkembangan teknologi usaha kue. UKM semisal teknologi pengovenan secara otomatis, teknologi pendinginan roti, teknologi pembungkusan roti. Teknologi ini dapat diterapkan untuk skala UKM, tentunya pemakaian teknologi juga harus melihat pangsa pasar terlebih dahulu sehingga nilai ekonomis dalam memanfaatkan alat tersebut sebanding dengan pemasukannya. (5) Penggunaan teknologi informasi. Era keterbukaan informasi memungkinkan semua informasi mengalir begitu cepat. Semakin pesatnya aliran informasi mendorong setiap perusahaan untuk secepat mungkin mendapatkan informasi yang bermanfaat bagi perusahaannya karena mereka tidak ingin ketinggalan dengan perusahaan pesaing lainnya sehingga dibutuhkan teknologi untuk mengaksesnya. Salah satu alat untuk mengakses informasi cepat tersebut adalah komputer yang telah terhubung dengan penyedia Jasa internet, Komputer dengan internet adalah satu paket untuk mengakses semua informasi yang berasal dari dunia maya.

Ancaman merupakan faktor strategis eksternal yang harus dimanfaatkan dengan sebaikbaliknya untuk mencapai tujuan dalam rangka pengembangan UKM. Faktor eksternal yang termasuk dalam kategori ancaman adalah: (1) kenaikan harga bahan baku utama. Harga bahan baku utama yang sering tidak menentu menyebabkan penentuan harga pokok produksi juga sering berubah terutama bahan baku utama yakni tepung terigu. Hal ini berpengaruh terhadap keuntungan yang didapatkan dan dapat mengakibatkan ketidakpastian harga yang akan dberikan kepada konsumen, jika hal ini terjadi dikhawatirkan konsumen akan beralih yang akan mengakibatkan, terjadinya penurunan penjualan. Untuk mengatasi hat tersebut perusahaan hendaknya dapat memberikan pelayanan kepada pembeli secara lebih baik lagi sehingga diharapkan pembeli tidak akan terlalu berpengaruh terhadap harga.

(2) Fluktuasi permintaan. Keadaan-keadaan tertentu yang menyebabkan konsumsi turun dan naik seperti musim libur sekolah, bulan pUasa, pemilu, dan hari-hari besar. Kondisi seperti diatas menyebabkan konsumsi kue di masyarakat cenderung tidak stabil yang juga menurunkan bahkan menaikkan omset penjualan dari perusahaan kue. (3) Perubahan selera konsumen. UKM sebagai perusahaan yang ingin terus tumbuh dan berkembang akan selalu melakukan inovasi yang disesuaikan dengan kebutuhan konsumen. Diferensiasi produk merupakan komponen penting di dalam jenis usaha UKM, hal ini didukung oleh pernyataan Salamah (2001) yang menyatakan bahwa sampai saat ini strategi diferensiasi telah diyakini oleh pelaku bisnis sebagai suatu kekuatan untuk mampu melawan pesaingnya dan merebut pangsa pasar yang lebih luas, tetapi menciptakan diferensiasi yang berarti itu adalah hal yang tidak mudah, tidak setiap perbedaan adalah pembeda. Perbedaan yang dibuat harus memenuhi beberapa kriteria yaitu: penting, unik, unggul, dapat dikomunikasikan, mendahului dan terjangkau, sehingga mampu menciptakan suatu posisi kompetitif yang berarti dan berbeda dalam benak pelanggan sasarannya. Pengembangan produk yang biasanya diadakan oleh Dinas Deperindagkop maupun asosiasi-asosiasi perusahaan roti. (4) Masuknya pesaing baru. Dalam data Euro monitor Internasional yang dirilis November 2009, jumlah kue yang diproduksi oleh usaha rumah tangga mencapai 25,6 juta ton. Nilai dari penjualan kue di segmen rumah tangga mencapai Rp. 1,2 trilyun. 
(5) Biaya transpotasi tinggi. Kenaikan harga bahan bakar minyak (BBM) terutama bensin berpengaruh signifikan terhadap biaya transportasi yang dikeluarkan oleh perusahaan. Kenaikan harga BBM di dalam negeri ini mengikuti harga minyak dunia yang memiliki kecenderungan akan naik secara terus menerus, seperti diketahui BBM merupakan energi yang tidak terbarukan sehingga persediaannya semakin lama semakin menipis, dan sesuai hukum ekonomi kelangkaan barang akan diikuti dengan kenaikan harga. Adanya kenaikan harga BBM juga akan berpengaruh terhadap harga pokok produksi yang akan ikut naik. Biaya transportasi juga mencakup harga suku cadang kendaraan yang juga cenderung naik. Adanya biaya transportasi yang tinggi ini memaksa perusahaan juga turut menaikkan harga jual rotinya, untuk mengatasi hal tersebut perusahaan hendaknya memberikan pelayanan kepada pembeli secara lebih baik lagi dan menciptakan produk-produk yang baru yang mampu mendorong seseorang untuk membeli. Evaluasi faktor eksternal merupakan langkah untuk merencanakan dan mengarahkan tindakan yang akan diambil perusahaan berdasarkan perkembangan faktor eksternal yang mempengaruhi (Pearce \& Robinson, 2007). (6) Hasil analisis lingkungan eksternal yang menghasilkan beberapa faktor peluang dan ancaman.

Kekuatan merupakan faktor strategis internal yang harus dimanfaatkan dengan sebaikbaliknya untuk mencapai tujuan dalam rangka pengembangan UKM. Faktor Internal yang termasuk dalam kategori kekuatan adalah: (1) faktor komitmen pemilik yang kuat terhadap perusahaan dalam pengembangan UKM; (2) faktor terhadap produk yang dimiliki spesifik, yang menunjukkan bahwa produk spesifik; (3) faktor kompetensi SDM, kompetensi SDM memiliki peranan dalam pengembangan UKM; (4) faktor kualitas produk yang baik; (5) faktor tingkat loyalitas pegawai terhadap perusahaan.

Kelemahan merupakan faktor strategis internal yang harus diperhatikan dengan sebaikbaiknya untuk mencapai tujuan dalam rangka pengembangan UKM. Faktor Internal yang termasuk dalam kategori kelemahan adalah: (1) faktor fungsi marketing yang belum maksimal; (2) faktor keterbatasan modal usaha; (3) faktor akses lokasi produksi yang kurang strategis memiliki; (4) faktor produk memerlukan perlakuan yang istimewa dalam bidang produksi; (5) faktor tingkat keterampilan SDM produksi perusahaan.

\section{Analisis Alternatif Strategi dengan Matriks TOWS}

Dalam merumuskan strategi pengembangan UKM, langkah selanjutnya menentukan posisi pengembangan UKM adalah dengan membuat suatu matriks untuk menghasilkan beberapa alternatif strategi Langkah tersebut dilakukan melalui penggabungan faktor eksternal dan internal yang dikenal dengan nama matriks TOWS.

Alternatif-alternatif strategi SWOT dibuat dalam rangka menjaga dan mempertahankan pengembanganUKM. Alat analisis dapat digunakan sebagai bahan pertimbangan untuk menyeleksi alternatif yang dihasilkan pada matriks TOWS, sehingga pada akhirnya terdapat keterkaitan antar masing-masing alat analisis. Langkah ini juga akan mendukung untuk dihasilkannya prioritas strategi yang merupakan hasil sintesis dari tahapan strategi yang mengolah pendapat dari para responden ahli. Hal ini sesuai dengan langkah yang disarankan oleh David (2009), dalam upaya untuk merumuskan strategi dengan membagi tiga tahap, yaitu tahap input, pencocokan, dan pengambilan keputusan. Dari hasil analisis penggabungan factor internal dan eksternal melalui matriks TOWS, maka alternatifalternatif strategi pengembangan UKM terpilih diperoleh sebagai berikut:

\section{Strategi SO (Strengths-Opportunities)}

Beberapa strategi yang didapatkan dari kombinasi dalam mengelola kekuatan pengembangan UKM dengan memanfaatkan peluang adalah: (1) membuka outlet. Strategi dalam membuka took dengan menggunakan merek sendiri dan menjual produk. Menurut Sumarwan (2004) merek adalah simbol dan indikator kualitas dari sebuah produk. Merek-merek produk yang sudah lama dikenal olah 
konsumen telah meqjadi sebuah citra bahkan simbol status bagi produk tersebut. Maka tidaklah mengherankan jika merek seringkali dijadikan kriteria dalam mengevaluasi suatu produk. Adanya label halal dan label PIRT (IzIn Dinas Kesehatan) pada kemasan dapat memberikan jaminan kepada konsumen bahwa produk yang dilepas ke pasaran telah melalui tahapan-tahapan keamanan pangan yang telah disertifikasi oleh instansi yang berwenang. Diharapkan dengan adanya informasi ini konsumen tidak merasa khawatir terhadap produk yang akan mereka konsumsi.

(2) Memperluas kemitraan dengan toko-toko besar. Pertimbangan untuk melaksanakan strategi ini adalah adanya kekuatan untuk memperluas kemitraan dengan took-toko besar dan memanfaatkan peluang untuk penyebaran produk. Kemasan produk merupakan salah satu media promosi yang dapat digunakan oleh perusahaan tempat mitra baru akan diajak bekerjasama.

\section{Strategi WO (Weakness-Opportunities)}

Beberapa strategi yang didapatkan dari kombinasi memanfaatkan peluang dan mengatasi kelemahan dalam pengembangan UKM yaitu dengan meningkatkan fungsi marketing. Strategi ini dapat dilakukan dengan mempertimbangkan peluang yang dapat dimanfaatkan.

\section{Strategi ST (Srengths-Threats)}

Strategi yang didapatkan dari kombinasi antara mengelola kekuatan pengembangan usaha UKM dan pengelolaan oleh manajemen dalam hal mengantisipasi berbagai ancaman adalah dengan menambah atau menciptakan variasi produk. Pihak manajemen dapat melakukan strategi ini dengan mempertimbangkan pengelolaan kekuatan UKM yaitu komitmen pemilik yang kuat dan kompetensi SDM dalam melakukan variasi berbagai macam varian produk, dan mengantisipasi ancaman bagi perusahaan yaitu perubahan selera konsumen, dan masuknya pesaing baru.. Adanya ancaman perubahan selera konsumen dan masuknya pesaing baru akan memaksa perusahaan untuk lebih berinovasi dalam mengolah produk-produk yang akan dipasarkan melihat dari kekuatan UKM dalam hal ini kompetensi SDM maka strategi ini dapat dimaksimalkan.

\section{Strategi WT (Weaknesses-Threats)}

Beberapa strategi yang didapatkan dari kombinasi antara mengatasi kelemahan pengembangan UKM dan mengantisipasi ancamannya adalah: (1) mengajukan kredit bank. Strategi ini dibuat berdasarkan kombinasi antara mengatasi kelemahan UKM. Dengan mengajukan kredit bank, UKM diharapkan dapat menghadapi ancaman-ancaman yang mempengaruhi pengembangan usaha UKM seperti kenaikan harga bahan baku utama, fluktuasi permintaan, dan perubahan selera konsumen. Fluktuasi permintaan yaitu pengaruh kondisi-kondisi tertentu seperti libur sekolah, bulan puasa, pemilu, dan hari-hari besar. Di mana kondisi tertentu tersebut permintaan bisa melonjak tajam mecapai $70 \%$ dari permintaan di hari biasa. (2) Investasi dalam teknologi pengolahan tepat guna. Investasi pada usaha kue terus meningkat dengan pesat. Namun investasi perlu perhitungan yang cermat dan jitu agar menghasilkan produk yang bermutu, handal, efisien sehingga tingkat pengembalian investasi dapat diraih dengan maksimal.

\section{PENUTUP}

Alternatif strategi yang dihasilkan dari analisis analisis SWOT, adalah: (1) meningkatkan fungsi marketing; (2) meningkatkan kemitraan dengan toko-toko besar; (3) menambah atau menciptakan variasi produk; (4) investasi pada teknologi produksi yang tepat guna; (5) meningkatkan permodalan dengan kredit bank, membuka toko dengan menggunakan merek sendiri. Melihat simpulan yang ada maka dapat diharapkan industry UKM dapat mempergunakannya untuk 
pengembangan usahanya. Hanya saja, tidak semua UKM dapat melakukan strategi ini. Karena strategi ini lebih mengarah pada UKM di usaha pangan. Usaha pangan disini berupa produk yang memiliki kadaluarsa tidak terlalu lama. Seperti roti dan kue, serta panganan ringan.

\section{DAFTAR PUSTAKA}

Ackoff, R. L. (1978). The Art of Problem Solving, New York: John Wiley.

Cooper, D. R., \& Schindler, P. S. (2006). Marketing Research. New York: McGraw-Hill.

David, F. R. (2009). Manajemen strategis. Jakarta: Salemba Empat.

Hussey, D. (1999). Strategic and planning (a manager’s guide), England: John Wiley \& Sons.

Pearce, J. A., \& Robinson, R. B. (2007). Strategic Management: formulation, implementation, and control. New York: McGraw-Hill. 